\title{
Intramolecular Hydroaminations of Aminoalkynes Catalyzed by Yttrium Complexes and Aminoallenes Catalyzed by Zirconium Complexes
}

\author{
Hyunseok Kim, T. Livinghouse, ${ }^{+*}$ Dong Seomoon, and Phil Ho Lee* \\ Department of Chemistry, Kangwon National Lniversity, Chunchon 200-701, Korea. ${ }^{*}$ E-mail phlee Q Kangnon ac.kr

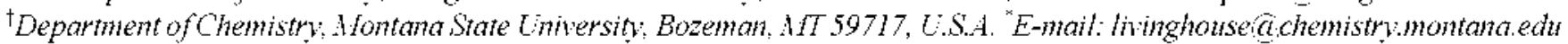 \\ Received March 27, 2007
}

\begin{abstract}
It was demonstrated that $\mathrm{Y}\left[\mathrm{N}(\mathrm{TMS})_{2}\right]_{3}$, the neutral yttrium-diamine complex 13 and ytrium-NPS complexes $\mathbf{1 5}$ are efficient precatalysts for intramolecular hydroamination of aminoalkynes involving primary amines. Complex 13 and 15 were quantitatively prepared in sitt by direct metalation of the ligands 4 and 9 with 1 equiv of $\mathrm{Y}\left[\mathrm{N}(\mathrm{TMS})_{3}\right]_{3}$ in benzene-d $\mathrm{d}_{6}$ at $120^{\circ} \mathrm{C}$ for 5 days and 10 days. respectively. via elimination of (TMS) $\mathrm{NH}$. 5-Exo- and 6-exo-dig intramolecular hydroamination of aminoalkynes using catalyst 12 and 13 proceeded smoothly to give nitrogen-contained cyclic products in good to excellent yields in all cases. In the case of 7exo-dig intramolecular hydroamination, the desired product was produced in $41 \%$ and $48 \%$ yields despite the gem-dimethyl effect. However. treatment of catalyst 15 with aminoalkynes (19 and 22) having a methyl substituent at the carbon adjacent to triple bond and 6-ero-dig intramolecular hydroamination of $\mathbf{2 1}$ failed to give the desired products. Zirconium-catalyzed intramolecular hydroamination of aminoallenes (25. 27. and 31) with $5 \mathrm{~mol} \% 16$ afforded 2-(trans-1-propenyl)pyrrolidine. 2-isopropylenepy rrolidine. and 2-(trans-1propenylypiperidine in $96 \%, 95 \%$. and $93 \%$ yield. respectively. However. subjecting 25 to $5 \mathrm{~mol} \% \mathbf{1 5}$ was unsuccessful to produce the desired product.
\end{abstract}

Key Words : Intramolecular hydroamination, Aminoalkyne, Aminoallene. Yttrium, Zirconium

\section{Introduction}

Transition metal-catalyzed intramolecular hydroamination of aminoalkynes and aminoallenes has been regarded as a powerful method for the sy'nthesis of nitrogen-contained heterocyclic compounds. ${ }^{1}$ Early metal-based catalysts for this conversion are well-suited for hydroaminations of aminoalkenes and aminoalkynes under mild reaction conditions. Various complexes that have been historically used for this purpose are relatively air- and moisture-sensitive metallocene derivatives. ${ }^{2}$ Recently organolanthanide-catalyzed processes have been expanded bey'ond the ability to form $\mathrm{C}-\mathrm{C}$ bonds. Also these organometallics are recognized to produce new $\mathrm{C}-\mathrm{N}$ bonds efficiently by insertion of alkenes and alkynes into the metal-nitrogen bond of organolanthanide amides. ${ }^{3}$ Effective non-metallocene lanthanide as well as group 3 cataly sts were recently described for hydroamination reaction of aminoalkenes and aminoalkynes. ${ }^{+}$We found that simple amido derivatives of the group 3 metals corresponding to the formula $\operatorname{Ln}\left[\mathrm{N}(\mathrm{TMS})_{2}\right]_{3}$ ( $\mathrm{Ln}=$ lanthanide. $\mathrm{TMS}=$ trimethỵ 1 sily $\mathrm{l})$ and $\left[\mathrm{L}_{\hat{\mathrm{S}}} \mathrm{YN}(\mathrm{TMS})_{2}(\mathrm{~L}=\right.$ ligand $\left.)\right]$ are efficient catalysts for intramolecular hydroamination of aminoalkenes and aminoalky'nes and that zirconium(IV) complexes are fruitful catalyst for intemal alkene hydroaminations." Herein. $\mathrm{L}_{2} \mathrm{YN}(\mathrm{TMS})$ ) obtained from coordination of the active metal center to simple chelating diamide ligands could be effectively applied to intramolecular hydroanunation of aminoalkynes and the neutral zirconium(IV) complex derived from $\mathrm{Zr}\left(\mathrm{NMe}_{2}\right)_{4}$ and NPS ligand has been shown to be an effective precatalyst for intramolecular
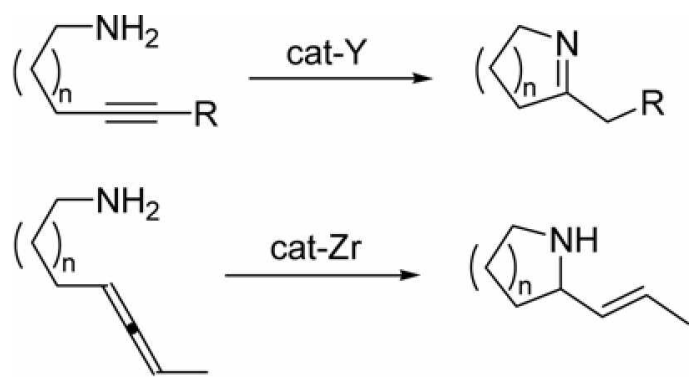

Scheme 1. Inromolecular hydroamination of aminoalkynes and aminoallenes.

hydroamination of aminoallenes. producing the cyclic amines in good to excellent yields (Scheme 1). ${ }^{6}$

\section{Results and Discussion}

Preparation of Ligand, Precatalyst, Aminoalkynes, and Aminoallenes: 1.2-Diamine proligand (4) was prepared by the reaction of 2-isopropylaniline (2) with oxalyl chloride (i) in the presence of triethylamine followed by reduction with LAH (Scheme 2). Treatment of 2.6-diethylaniline (6) with glyoxal (5) in the presence of catalytic amounts of formic acid in methanol gave 1.2-diimine compounds followed by reduction with LAH to afford the desired product (7) in $88 \%$ yield. The thiophosphinic amides ( 9 and 11) were prepared in $43 \%$ and $68 \%$ yields. respectively. by the reaction of 2.3-dimethyl-2.3-butanediamine (8) and 2.2dimethyl-1.3-diamine (10) with 2.1 equiv of diisopropyl- 


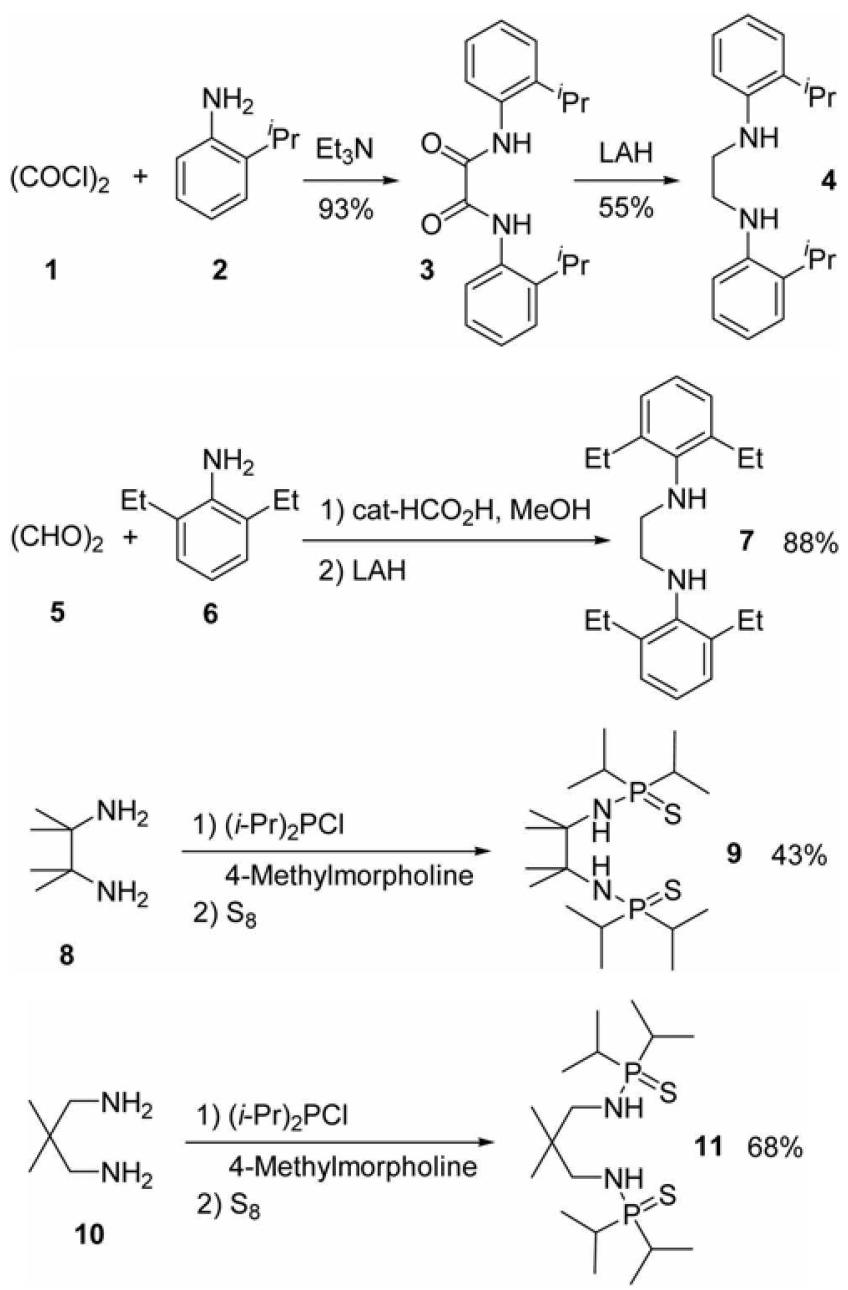

Scheme 2. Preparation of 1,2-diannines and NPS ligands.

chlorophosphine followed by the addition of 2.2 equiv of sulfur.

As part of our previous study ${ }^{5 / 2}$ we noted that treatment of a variety of aminoalkenes with catalytic amounts of $\mathrm{Y}\left[\mathrm{N}(\mathrm{TMS})_{2}\right]_{3}(12)$ in benzene- $\mathrm{d}_{6}$ at $24^{\circ} \mathrm{C}$ resulted in generation of the corresponding amine-ligated amido complexes ${ }^{7}$ accompanying the instantaneous liberation of (TMS) $=\mathrm{NH}$. It is well established that the catalytic activity of group 3 metallocenes in hydroanination of aninoalhynes is effected by steric hindrance about the metal center. ${ }^{3}$ In the light of this, we began to examine the role that sterically hindered chelating diamide ligands might play in changing the reactivity of group 3 and 4 amido complexes (Scheme 3 ). Although metallation reaction of $N N^{\prime}$-bis(2.6-diethylpheny)ethylenediamine (7) to yttrium was not completed even after 5 days attaclument of the ligand 4 to yttrium was quantitatively achieved by the direct metalation with 1 equiv of $\mathrm{Y}\left[\mathrm{N}(\mathrm{TMS})_{2}\right]_{3}$ in benzene-d $\left(120^{\circ} \mathrm{C} .5\right.$ days $)$ to afford complex 13 via extrusion of (TMS) $)_{\Sigma} \mathrm{NH}$. Ligand exchange reaction of $N, N^{\prime}$-bis $(\mu . P$-diisopropy lthiophosphinyl)-2.3dimethyl-2.3-butanediamine (9) with $\mathrm{Y}\left[\mathrm{N}(\mathrm{TMS})_{2}\right]_{3}$ proceeded to produce precatalyst 15 in benzene- $\mathrm{d}_{6}\left(120^{\circ} \mathrm{C} .10\right.$ days $)$ vic elimination of bis(trimethylsily l)anine. Also, attachment

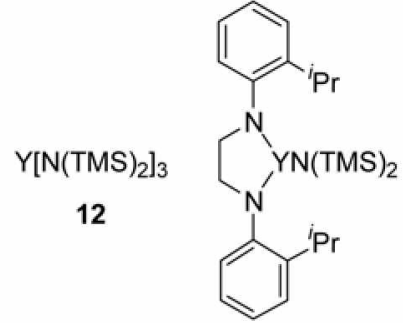

13

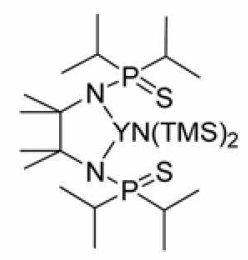

15<smiles>CCc1cccc(CC)c1N1CCN(c2c(CC)cccc2CC)N1C(C)(C)C</smiles>

14

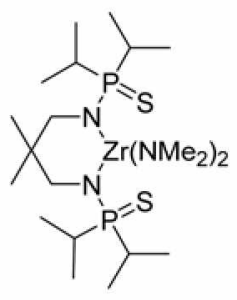

16

$4+\mathrm{Y}\left[\mathrm{N}(\mathrm{TMS})_{2}\right]_{3} \frac{\mathrm{C}_{6} \mathrm{D}_{6}}{120{ }^{\circ} \mathrm{C}, 5 \mathrm{~d}} 13+2(\mathrm{TMS})_{2} \mathrm{NH}$

$9+\mathrm{Y}\left[\mathrm{N}(\mathrm{TMS})_{2}\right]_{3} \frac{\mathrm{C}_{6} \mathrm{D}_{6}}{120^{\circ} \mathrm{C}, 10 \mathrm{~d}} 15+2(\mathrm{TMS})_{2} \mathrm{NH}$

$11+\operatorname{Zr}\left(\mathrm{NMe}_{2}\right)_{4} \frac{\mathrm{C}_{6} \mathrm{D}_{6} \text { or } \mathrm{C}_{6} \mathrm{D}_{5} \mathrm{CD}_{3}}{25^{\circ} \mathrm{C}, 10 \mathrm{~min}} 16+2 \mathrm{Me}_{2} \mathrm{NH}$

Scheme 3. In situ generation of yttrium and zirconium precatalyst for hydroamination.

of the proligand 11 to zirconium was quantitatively attained by the direct metalation with 1 equiv of $\mathrm{Zr}\left(\mathrm{NMe}_{2}\right)_{4}$ in benzene- $\mathrm{d}_{6}$ or toluene- $\mathrm{d}_{9}\left(25^{\circ} \mathrm{C} .10 \mathrm{~min}\right)$ to give complex 16 [NPS $\mathrm{Zr}\left(\mathrm{NMe}_{2}\right)_{2}$ wia dimethy lamine liberation. The ${ }^{1} \mathrm{H} \cdot{ }^{12} \mathrm{C}$, and ${ }^{31} \mathrm{P}$ NMR spectra of 16 are consistent with a monomeric species possessing an octahedral structure in which both dimethylamino ligands are axial. The $\mathrm{NMe}_{2}$ resonance (500 $\mathrm{MHz}$ ) appears as a sharp singlet at $3.11 \mathrm{ppm}$ and the linker $\mathrm{CH}_{2}$ as a doublet $(2.69 \mathrm{ppm} . J=10 \mathrm{~Hz})$. The signal for the $\mathrm{CH}$ adjacent to phosphorus appears as a well defined septet centered at $2.00 \mathrm{ppm}(J=7 \mathrm{~Hz})$, with the diastereomeric isopropyl methyls appearing as a set of doublets between 1.16 and $1.10 \mathrm{ppm}(J=7 \mathrm{~Hz})$. The ${ }^{31} \mathrm{P}$ spectrum of $\mathbf{1 6}$ reveals a singlet at $75.10 \mathrm{ppm} .{ }^{8}$ The thermal stability of $\mathbf{1 6}$ was described by heating it at $150^{\circ} \mathrm{C}$ for $19 \mathrm{~h}$. whereupon no alteration of the NMR spectra was detected.

Synthetic procedures for the synthesis of a variety of aninoalkynes are shown in Scheme 4. 5-Phenyl-4-penty'n-1amine (17) was prepared by the reaction of phenylacetylene with 3-bromo-1-chloropropane using $n$-BuLi followed by a Gabriel reaction. 2-Amino-5-decyne (18) was obtained from the 1.4-addition of 1-hexyne to methyl vinyl ketone and reductive amination. The reaction of 2-bromo-3-octyne. derived from l-hexyne and acetaldehyde. with lithiated acetonitrile followed by $\mathrm{LAH}$ reduction of nitrile produced 1-amino-3-methyl-4-nonyne (19). Also. preparations of 20 


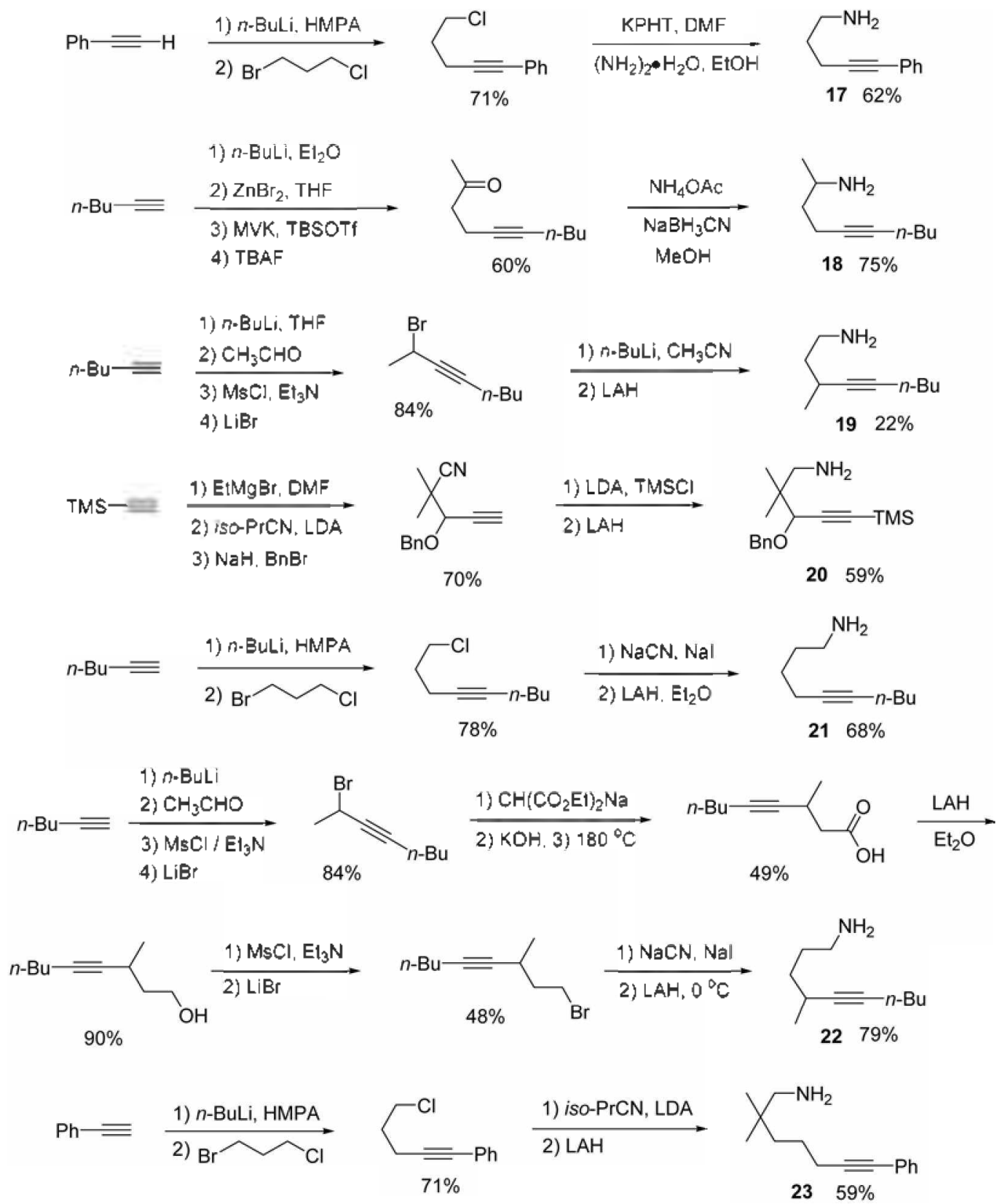

Scheme 4. Preparation of a variety of aminoalkynes.

and 22 could be achieved by using standard organic reactions. 1-Anino-5-decyne (21) and 1-anino-2.2-dintethyl-7phenyl-6-heptyne (23) were prepared by alkylation of the correspondding acetylene and substitution by cyanide anion followed by reduction of nitrile with $\mathrm{LAH}$.

4.5-Heptadien-1-amine (25), 6-methỵl-4.5-heptadien-1amine (27), and 5.6-octadien-1-amine (31) were prepared from 3-butỵn-2-ol. 2-methỵl-3-butỵn-2-ol. and 4-pentyn-1ol. respectively (Scheme 5). 3.4-Hexadien-1-ol (24) was produced from the reaction of 3-butyn-2-ol with triethyl orthoacetate in the presence of catalytic amount of propionic acid followed by LAH reduction. Sulfonation of 24 with tosyll chloride. substitution of tosylate with sodium cyanide and then. $\mathrm{LAH}$ reduction gave rise to 25 . Also. compound 27 was similarly prepared to 25 . Compound 31 was easily obtained from standard organic reactions.

Yttrium-catalyzed Intramolecular Hydroamination of Aminoalkynes: First. the intramolecular hydroamination of 5-phenyl-4-pentyn-1-amine (17) was selected for initial examination of the catalytic activity of the complexes 12.13. and 15. The results are summarized in Table 1. Reaction of 17 with $\left.5 \mathrm{~mol} \% \mathrm{YN}(\mathrm{TMS})_{2}\right]_{3}$ (12) and 13 gave rise to the desired product 3,4-dylydro-5-(phenylmethyl)-2H-pyrrole (32) in $90 \%\left(25^{\circ} \mathrm{C}, 480 \mathrm{~h}\right)$ and $67 \%\left(25^{\circ} \mathrm{C}, 330 \mathrm{~h}\right)$ yields, respectively. wia 5-exv-dig intramolecular hydroamination (entries 1 and 3) in J. Young NMR tube (benzene- $\mathrm{d}_{6,0.46}$ M). Heating the reaction mixture at $60^{\circ} \mathrm{C}$ with $5 \mathrm{~mol} \%$ $\mathrm{Y}\left[\left.\mathrm{N}(\mathrm{TMS})_{2}\right|_{3}\right.$ proceeded more rapidly to afford 32 in $90 \%$ yield after $89 \mathrm{~h}$ (entry 2). Exposure of $13(5 \mathrm{~mol} \%$ ) to 17 produced azacycles in $94 \%$ y ield $\left(60^{\circ} \mathrm{C} .9 \mathrm{l}, 1.0 \mathrm{M}\right.$, entry 5$)$. 
<smiles>C#CC(C)O</smiles>

1) cat-propionic acid $\mathrm{CH}_{3} \mathrm{C}(\mathrm{OEt})_{3}$

2) $\mathrm{L}_{|\mathrm{A}| \mathrm{H}_{4}, \mathrm{THF}, 84 \%}$<smiles>CC=C=CCCO</smiles>

24
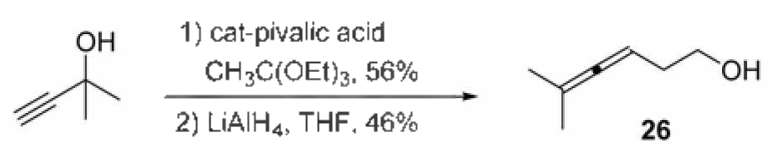

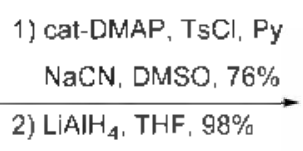

1) $\mathrm{TsCl}, \mathrm{Py}, \mathrm{CH}_{2} \mathrm{Cl}_{2}$ NaCN. DMSO $65 \%$ 2) $\mathrm{LIAIH}_{4}, \mathrm{THF}, 82 \%$
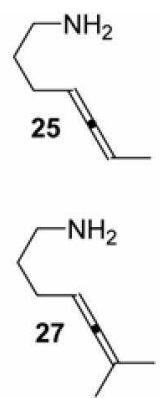

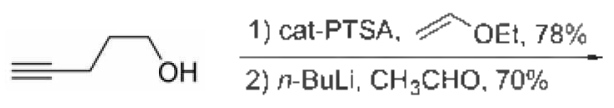

1) cat-PTSA, 2 OEt, $78 \%$ -

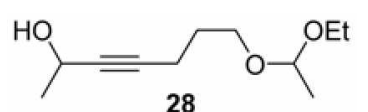

28
1) $\mathrm{MsCl}_{2} \mathrm{Et}_{3} \mathrm{~N}, 94 \%$

3) $\mathrm{Mel}_{1} 98 \%$

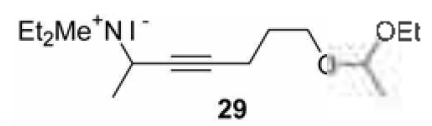

29
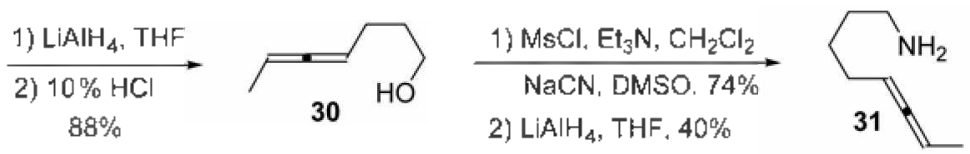

Scheme 5. Preparation of 4,5-heptadine-1-annine, 6-methy1-4,5-heptadien-1-amine, and 5,6-octadien-1-amine.

Table 1. Reaction optimization of yttrium-catalvzed intramolecular hydroanination of 5-pheny]-4-pentyn-1-amine ${ }^{i}$

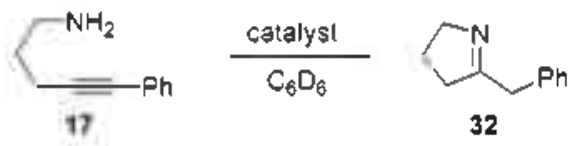

\begin{tabular}{cccccc}
\hline Entry & Catalyst & Conc. [M] & Temp. ['C] & Time [h] & Yield [\%] \\
\hline 1 & $\mathbf{1 2}$ & 0.46 & 25 & 480 & 90 \\
2 & $\mathbf{1 2}$ & 0.46 & 60 & 89 & 90 \\
3 & $\mathbf{1 3}$ & 0.46 & 25 & 330 & 67 \\
4 & $\mathbf{1 2}$ & 1.0 & 60 & 80 & 96 \\
5 & $\mathbf{1 3}$ & 1.0 & 60 & 9 & $94(85)^{\circ}$ \\
6 & $\mathbf{1 5}$ & 1.0 & 60 & 1.5 & 96 \\
\hline
\end{tabular}

"Reaction pertormed in the presence of 5 mol 0.0 catalyst in benzene- $\mathrm{d}_{6}$. "NMR yields based on $p$-ivene as an internal standard. "Isolated vield.

The reaction of 15 with $17\left(60^{\circ} \mathrm{C} .1 .5 \mathrm{~h}, 1.0 \mathrm{M}\right)$ afforded 32 in $96 \%$ yield (entry 6 ).

Stimulated by these results. we applied a variety of yttrium-catalysts to intramolecular hydroamination of aminoalkynes to establish the efficiency and scope of the present method. The results are summarized in Table 2 . Treatment of 20 with $5 \mathrm{~mol} \% 12.13$. and 15 produced 35 in $98 \%$ yields (by NMR), respectively. after $0.2 \mathrm{~h}$ at $25^{\circ} \mathrm{C}$ (entries 10-12). Also, aninoalhyne 18 possessing a methyl group at the carbon attached to nitrogen was smoothly cyclized with $\mathbf{1 2}$ to provide 33 in $95 \%$ yield $\left(25^{\circ} \mathrm{C} .0 .2 \mathrm{~h}\right.$, entry 4). These results suggest that cyclization of these substrates would be accellerated by the gem-dimethyl effect. ${ }^{\text {ja }}$ Hydroamination reaction of 18 using 13 and 15 proceeded to give 33 in good yields (entries 5 and 6 ). Although the reaction of 19 with 12 and 13 afforded the desired product 34 in $92 \%$ and $81 \%$ yields. respectively. (entries 7 and 8 ). ${ }^{11}$ the use of $\mathbf{1 5}$ as a cataly st failed to produce the desired product (entry 9). In addition. exposure of 21 and 22 to 15 did not give the cyclized product (entries 15 and 18). Hydroamination of $\mathbf{2 2}$ having a methyl group at the carbon adjacent to the triple bond with 13 proceeded more rapidly to provide 37 in $92 \%$ yield [benzene-d $\mathrm{d}_{\mathrm{G}}$ at $150{ }^{\circ} \mathrm{C}$ for $18 \mathrm{~h}$ (entry 17)]. while the reaction of 21 with 13 ( $5 \mathrm{~mol} \%$ ) furnished the cyclized product 36 in $93 \%$ yield in $\mathrm{C}_{6} \mathrm{D}_{6}$ at $150^{\circ} \mathrm{C}$ for $71 \mathrm{~h}$ (entry 14). ${ }^{11}$ Subjecting 23 to $13(5 \mathrm{~mol} \%)$ resulted in the production of 38 in $48 \%$ yield, albeit under harsh conditions (benzene-di, $120^{\circ} \mathrm{C} .158 \mathrm{~h}$ ) (entry 20). The present conditions were ineffective for the secondary amine.

Zirconium-catalyzed Intramolecular Hydroamination of Aminoallenes: Encouraged by yttrium-catalyzed intramolecular hydroamination of aminoalkynes, we next examined the intramolecular hydroamination of aminoallenes (Scheme 6). Reaction of $\mathbf{2 5}$ and 27 with $5 \mathrm{~mol} \% \mathbf{1 6}$ afforded 2-(trans-1-propenyl)pyrrolidine (39) and 2-isopropylenepyrrolidine $(40)$ in $96 \%$ and $95 \%$ yield respectively. Subjecting 25 to $5 \mathrm{~mol} \% 15$ failed to produce the desired product. Exposure of 31 on $5 \mathrm{~mol} \% 16$ produced 2-(trans-1propenyl) piperidine (41) in $93 \%$ yield.

Mechanism: Mechanism of hydroamination reaction involving precatalyst 16 can be suitably observed by ${ }^{31} \mathrm{P}$ NMR. Exposure of 25 on a benzene- $\mathrm{d}_{6}$ solution of $5 \mathrm{~mol} \%$ 16 resulted in the immediate disappearance of the phosphorus resonance at $75.10 \mathrm{ppm}$ with conconitant appearance of a new signal at $76.58 \mathrm{ppm}$. The fact that this appeared with the production of $\mathrm{Me}_{2} \mathrm{NH}$ on ${ }^{1} \mathrm{H}$ NMR spectrum is strongly indicative of exchange of the amido ligands at zirconium. Cyclization of 25 at $75^{\circ} \mathrm{C}$ over $2 \mathrm{~h}$ resulted in $96 \%$ conversion to 39 with no change to the ${ }^{31} \mathrm{P}$ resonance at $76.58 \mathrm{ppm}$, thus providing evidence that the 2 irconium catalyst is robust under the reaction conditions. Moreover. ${ }^{31} \mathrm{P}$ resonance associated with the free proligand 11 at 89.54 ppm did not appear during this reaction. A plausible mechanistic pathway for the intramolecular hydroamination 
Table 2. Yttrium-catalyzed intramolecular hydroamination of aminoalky nes ${ }^{a}$

\begin{tabular}{|c|c|c|c|c|c|c|c|}
\hline Entry & Aminoalkyne & Catalyst & Temp. ["C] & Time [h] & Azacycle & & Yield $[\%]^{4}$ \\
\hline 1 & & 12 & 60 & 80 & & & 96 \\
\hline 2 & 17 & 13 & 60 & 9 & & 32 & 94 \\
\hline 3 & $=\mathrm{Ph}$ & 15 & 60 & 1.5 & & & 96 \\
\hline 4 & & 12 & 25 & 0.2 & & & 95 \\
\hline 5 & 18 & 13 & 25 & 1.5 & & 33 & 95 \\
\hline 6 & $\equiv n-\mathrm{Bu}$ & 15 & 75 & 3 & & & 95 \\
\hline 7 & & 12 & 120 & 3.5 & & & 92 \\
\hline 8 & 19 & 13 & 120 & 13 & & 34 & 81 \\
\hline 9 & $-n$-Bu & 15 & 120 & 17 & & & 0 \\
\hline 10 & & 12 & 25 & 0.2 & & & 98 \\
\hline 11 & 20 & 13 & 25 & 0.2 & TMS & 35 & 98 \\
\hline 12 & & 15 & 25 & 0.2 & & & 98 \\
\hline 13 & $\mathrm{NH}_{2}$ & 12 & 150 & 141 & & & 67 \\
\hline 14 & 21 & 13 & 150 & 71 & & 36 & 93 \\
\hline 15 & $\equiv-n-\mathrm{Bu}$ & 15 & 100 & 30 & & & 0 \\
\hline 16 & $\mathrm{NH}_{2}$ & 12 & 150 & 20 & & & 95 \\
\hline 17 & 22 & 13 & 150 & 18 & $n$-Bu & 37 & 92 \\
\hline 18 & $\equiv n-\mathrm{Bu}$ & 15 & 150 & 143 & & & 0 \\
\hline 19 & & 12 & 120 & 141 & & & 41 \\
\hline 20 & 23 & 13 & 120 & 158 & & 38 & 48 \\
\hline 21 & $=\mathrm{Ph}$ & 15 & 120 & $21^{c}$ & & & 56 \\
\hline
\end{tabular}

"Reaction performed in the presence of $5 \mathrm{~mol}^{\circ}$ i catalyst in benzene- $\mathrm{d}_{6}(1.0 \mathrm{M})$. "NMR yields based on $p$ - $x y$ lene as an internal standard. ${ }^{\circ}$ Days.

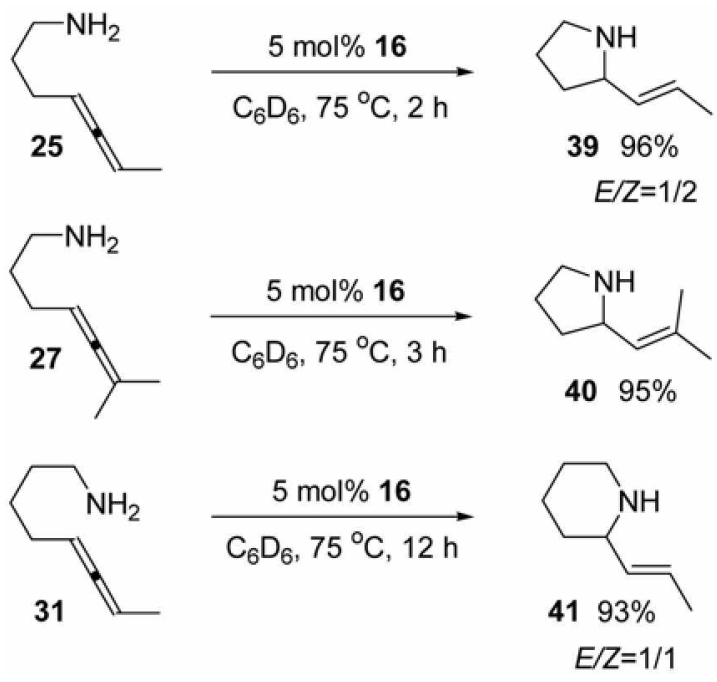

Scheme 6. Zirconiun-catalyzed intramolecular hydroamination of aminoallenes.

of 25 , involving the putative $\mathrm{Zr}$ (IV) inido complex $\mathbf{4 2 ^ { 1 1 }}$ and azazirconacyclobutane $\mathbf{4 3}$ based on these observations, is described in Scheme 7.
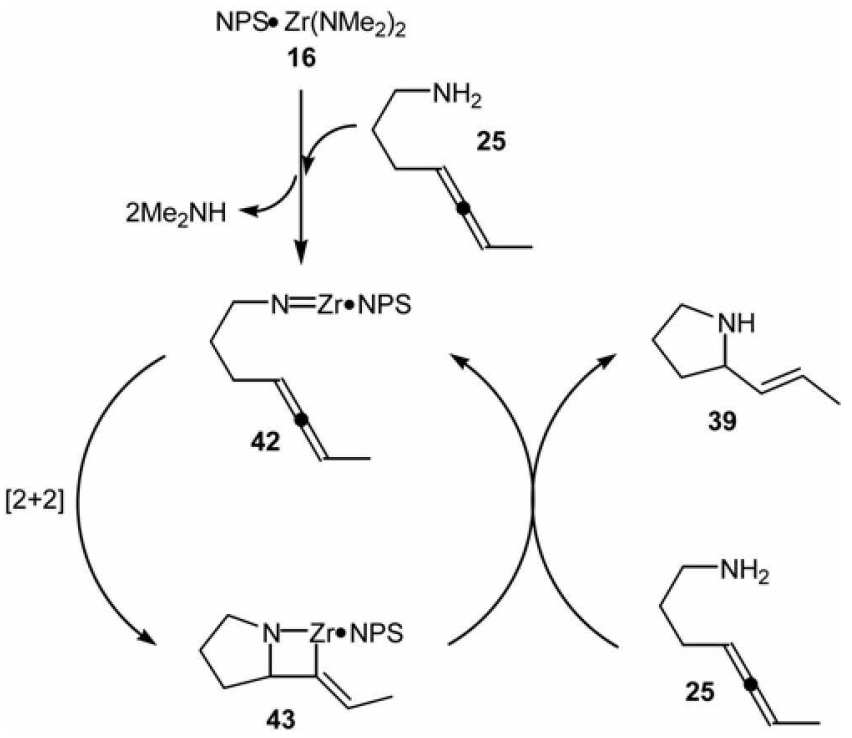

Scheme 7. Proposed mechanism for the hydroamination.

\section{Conclusions}

We have demonstrated that $\mathrm{Y}\left[\mathrm{N}(\mathrm{TMS})_{2}\right]_{3}$, the neutral 
yttrium-dianine complex 13 , and the yttrium-NPS complex 15 are efficient precatalysts for intramolecular hydroamination of primary aninoalkynes. Complexes 13 and 15 were quantitatively prepared in sint by direct metalation reactions of the ligands 4 and 9 with 1 equiv of $\mathrm{Y}\left[\mathrm{N}(\mathrm{TMS})_{2}\right]_{3}$ in benzene- $\mathrm{d}_{6}$ at $120^{\circ} \mathrm{C}$ for 5 days and 10 days. respectively. via elimination of (TMS): NH. 5-Exo- and 6-exo-dig intramolecular hydroamination of aminoalkynes using catalysts 12 and 13 proceeded smoothly to give nitrogen-contained cyclic products in good to excellent yields in all cases. In the case of 7-exo-dig intramolecular hydroanination. the desired product was produced in $41 \%$ and $48 \%$ yields despite the gem-dimethyl effect. However, treatment of catalyst $\mathbf{1 5}$ with aminoalkynes (19 and 22) having a methyl substituent at the carbon adjacent to the triple bond and 6-exo-dig intramolecular hydroamination of 21 failed to give the desired products. Zirconium-catalyzed intramolecular hydroamination of aminoallenes 25. 27. and 31 with $5 \mathrm{~mol} \% 16$ afforded 2-(trans-1-propenyl)pyrrolidine, 2-isopropylenepyrrolidine. and 2-(trans-1-propenyl)piperidine in 96\%. $95 \%$, and $93 \%$ yield. respectively. However. subjecting 25 to $5 \mathrm{~mol} \% 15$ failed to produce the desired product. Extention of this study is now under investigation in this laboratory

\section{Experimental}

General. Melting points were obtained using a Mel-Tenp II apparatus equipped with a digital thermometer and were uncorrected. Infrared spectra were recorded on a Perkin Elmer model 1600 FT-IR. Infrared spectra of solids were obtained by standard $\mathrm{KBr}$ pellet procedures. 'H NMR spectra were recorded on a Bruker AVANCE DPX-300 (300 $\mathrm{MHz})$ or AVANCE DPX-500 (500 MHz) spectrometer. J. Young NMR tubes were purchased from Aldrich or J. Young Ltd. Chemical shifts were reported in $\mathrm{ppm}$ from tetramethylsilane with the residual protic solvent resonance as the internal standard (chloroform: 7.27. benzene: 7.16. toluene: 7.09). ${ }^{13} \mathrm{C}$ NMR spectra were recorded on a Bruker AVANCE DPX-300 (300 MHz) or AVANCE DPX-500 (500 $\mathrm{MHz})$ spectrometer with complete decoupling. Chemical shifts were reported in $\mathrm{ppm}$ from tetramethylsilane with the solvent as the internal standard $\left(\mathrm{CDCl}_{3}: 77.23\right)$. Analytical thin layer chromatography was performed on Polygrami ${ }^{\text {ri }}$ SIL $G / U_{\text {Sิ }} 1.25 \mathrm{~mm}$ silica gel plates with a fluorescent indicator. Flash chromatography was performed on Merck silica gel 60 . Solvents for extraction and flash chromatography were reagent grade. All experiments were carried out under an argon atmosphere. Organozirconium and organoyttrium complexes were manipulated under an argon atmosphere in a glove box. Benzene- $d_{6}$ and toluene- $d_{s}$ were distilled from $\mathrm{Na}$ and aminoalkynes and aminoallenes were distilled from $\mathrm{CaH}_{2}$ under an argon atmosphere and stored at $-30^{\circ} \mathrm{C}$ in a glove box. J. Young NMR tubes. purchased from Aldrich or $\mathrm{J}$. Young Ltd. were used at the corresponding temperature with safety shield.

Preparation of $N, N^{\prime}$-bis(2-isopropylphenyl)ethane-1,2- diamine (t). To a solution of 2-isopropyl aniline (2.35 g. $17.4 \mathrm{mmol})$ and trietlyylamine $(2.64 \mathrm{~mL} .19 .0 \mathrm{mmol})$ in $\operatorname{THF}(60 \mathrm{~mL})$ at $0{ }^{\circ} \mathrm{C}$ was added dropwise oxalyl chloride $(1.0 \mathrm{~g} .7 .9 \mathrm{mmol})$. The reaction mixture was stirred overnight and then, refluxed for $\mathrm{l} \mathrm{h}$. After cooling to room temperature, the reaction mixture was diluted with ethyl acetate $(50 \mathrm{~mL})$. and then washed with $\mathrm{H}_{2} \mathrm{O}(20 \mathrm{~mL}), \mathrm{I} \mathrm{N}$ $\mathrm{HCl}(10 \mathrm{~mL})$, and sat. $\mathrm{NaHCO}_{3}(10 \mathrm{~mL})$. The organic layer was dried with anhydrous $\mathrm{MgSO}_{4}$. filtered. and evaporated in vacho to provide $N, N^{\prime}$-bis(2-isopropylphenyl)oxalamide $(2.5 \mathrm{~g}, 97 \%)$ as a white solid $\left(\mathrm{mp}=179-181^{\circ} \mathrm{C}\right) \cdot N, N^{\prime} \cdot \operatorname{Bis}(2-$ isopropylphenyl)oxalamide $(2.0 \mathrm{~g} .6 .16 \mathrm{mmol})$ was reduced by addition to $\mathrm{LiAlH}_{4}(0.47 \mathrm{~g}$. $12.3 \mathrm{mmol})$ in THF $(30 \mathrm{~mL})$ at room temperature and then. heating the resulting mixture at reflux ovenight. The reaction mixture was cooled to $0^{\circ} \mathrm{C}$ and carefully quenched via sequential addition of $\mathrm{H}_{2} \mathrm{O}(0.5$ $\mathrm{mL}), 15 \%$ aqueous $\mathrm{NaOH}(0.5 \mathrm{~mL})$ and $\mathrm{H}_{2} \mathrm{O}(\mathrm{lmL})$. The mixture was stirred at room temperature for $2 \mathrm{~h}$, and andydrous $\mathrm{MgSO}_{4}(\mathrm{l} .0 \mathrm{~g})$ was added. After filteration, the solvent was evaporated in wacho. The residue was purified by bulb-to-bulb distillation (160-165 ${ }^{\circ} \mathrm{C}$ at $0.5 \mathrm{mmHg}$ ) to afford $N . N^{\prime}$-bis(2-isopropylphenyl)ethane-1,2-diamine (4) $\left(1.0 \mathrm{~g} .55 \%\right.$ ) as a white solid (m.p. $47-48^{\circ} \mathrm{C}$ ). ${ }^{~} \mathrm{H}$ NMR (300 $\left.\mathrm{MHz}, \mathrm{CDCl}_{3}, 25^{\circ} \mathrm{C}\right): \delta=7.15(\mathrm{~m} .4 \mathrm{H}, \mathrm{ArH}) .6 .76(\mathrm{~m} .4 \mathrm{H}$, $\operatorname{ArH}$ ), 4.03 (bs, 2H. NH), 3.50 (s. $4 \mathrm{H}, \mathrm{CH}_{2}$ ), 2.85 (septet, $J=$ $6.9 \mathrm{~Hz}, 2 \mathrm{H} . \mathrm{CH}$ ). 1.22 (d. $\left.J=6.9 \mathrm{~Hz}, 12 \mathrm{H}, \mathrm{CH}_{3}\right) ;{ }^{13} \mathrm{C} \mathrm{NMR}$ $\left(75 \mathrm{MHz}, \mathrm{CDCl}_{3}, 25^{\circ} \mathrm{C}\right.$ ): $\delta=144.6,132.8,126.8 .125 .1$. $118.0,110.8,43.5,27.2,22.3 ; \operatorname{IR}(\mathrm{KBr}): v=3421.3,2959.5$, $2867.5,1602.3,1582.1 .1504 .7,1449.1,1305.6 .1256 .8$. $744.7 \mathrm{~cm}^{-1}$ : HR-MS (CI. NH $): m z=297.2368$, exact mass calcd for $\left[\mathrm{C}_{201} \mathrm{H}_{2} \mathrm{~N}_{2} \mathrm{H}\right]^{-}: 297.2331$.

$N, N^{\prime}$-Bis(2,6-diethylphenyl)ethylenediamine (7). To a solution of glyoxal $(1.14 \mathrm{~mL}, 9.85 \mathrm{mmol})$ and 2.6 -diethylaniline ( $3 \mathrm{~g} .19 .7 \mathrm{mmol}$ ) in $\mathrm{MeOH}(6 \mathrm{~mL})$ was added 2 drops of formic acid and stirred at room temperature overnight. The reaction mixture was concentrated in vactoo. and then, the crude compound was directly used for next reaction without further purification. The crude compound dissolved in THF $(5 \mathrm{~mL})$ was added dropwise to a suspension of $\mathrm{LiAlH}_{4}(750 \mathrm{mg}$. $19.7 \mathrm{mmol})$ in THF $(80 \mathrm{~mL}$ ), and then heated at reflux for $1 \mathrm{~h}$. The reaction mixture was cooled to 0 ${ }^{\circ} \mathrm{C}$ and carefully quenched via sequential addition of $\mathrm{H}_{2} \mathrm{O}$ (l $\mathrm{mL}), 15 \%$ aqueous $\mathrm{NaOH}(1 \mathrm{~mL})$ and $\mathrm{H}_{2} \mathrm{O}(2 \mathrm{~mL})$. The mixture was stirred at room temperature for $\mathrm{l} h$ and anlydrous $\mathrm{MgSO}_{4}(2 \mathrm{~g})$ was added, followed by filtration and concentration of the filtrate in vacto. The residue was purified by distillation $\left(139-149^{\circ} \mathrm{C}\right.$ at $\left.1 \mathrm{mmHg}\right)$ to provide 7 $(2.8 \mathrm{~g} .88 \%) .{ }^{1} \mathrm{H}$ NMR $\left(300 \mathrm{MHz} . \mathrm{CDCl}_{3} .25^{\circ} \mathrm{C}\right): \delta=6.97$ (m, $2 \mathrm{H}, \mathrm{ArH}$ ). 3.32 (bs. $2 \mathrm{H}$. NH). 3.10 (s. $4 \mathrm{H}$. $\mathrm{NCH}_{2}$ ). 2.62 (q. $\left.J=7.5 \mathrm{~Hz} .8 \mathrm{H} . \mathrm{CH}_{2}\right), 1.16\left(\mathrm{t} . J=7.5 \mathrm{~Hz} .12 \mathrm{H} \mathrm{CH}_{3}\right) ;{ }^{12} \mathrm{C}$ NMR (75 MHz. $\mathrm{CDCl}_{3 .} 25^{\circ} \mathrm{C}$ ): $\delta=144.9 .136 .4,126.7$, 122.9, 50.5. 24.4. 14.9; IR (neat): $v=3366.9,2963.4$,

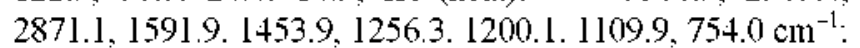
LR-MS (EI): $m z$ (relative intensity) $324\left(\mathrm{M}^{-} .14\right) .162$ (100), $147(29), 132(24)$

$N, N^{\prime}$-Bis( $P, P$-diisopropylthiophosphinyl)-2,3-dimethyl2,3-butanediamine (9). This compound was prepared in a 
fashion analogous to 11 utilizing 2.3-dimethyl-2,3-diaminobutane $(0.29 \mathrm{~g} .2 .5 \mathrm{munol})$. 4-methylmorpholine $(0.66 \mathrm{~mL} .6$ $\mathrm{mmol})$, and chlorodiisopropylphosphine $(0.8 \mathrm{~mL}, 5 \mathrm{mmol})$ in toluene $(15.5 \mathrm{~mL})$ at $70^{\circ} \mathrm{C}$, followed by the addition of sulfur $(0.17 \mathrm{~g}, 5.25 \mathrm{mmol})$. The residue was purified by column chromatography on silica gel to give $9(440 \mathrm{mg}$. $43 \%$ ). using $\mathrm{CH}_{2} \mathrm{Cl}_{2}$ for elution. m.p. $147-148{ }^{\circ} \mathrm{C} .{ }^{1} \mathrm{H}$ NMR $\left(300 \mathrm{MHz} . \mathrm{CDCl}_{3} .25^{\circ} \mathrm{C}\right.$ ): $\delta=2.69$ (bs. $2 \mathrm{H}$. NH) 2.19 (septet, $J=6.9 \mathrm{~Hz},+\mathrm{H} . \mathrm{CH}) .1 .44\left(\mathrm{~s} .12 \mathrm{H} . \mathrm{CH}_{3}\right), 1.22(\mathrm{~d}, J=$ $\left.6.9 \mathrm{~Hz} .12 \mathrm{H} . \mathrm{CH}_{3}\right), 1.19$ (d. $\left.J=6.9 \mathrm{~Hz}, 12 \mathrm{H}, \mathrm{CH}_{3}\right) ;{ }^{13} \mathrm{C}$ NMR $\left(75 \mathrm{MHz}, \mathrm{CDCl}_{3} .25^{\circ} \mathrm{C}\right): \delta=62.5\left(\mathrm{~d}, J_{\mathrm{s}-\mathrm{p}}=5.0 \mathrm{~Hz}\right)$. $31.4\left(\mathrm{~d}, J_{\mathrm{c}-\mathrm{p}}=67.3 \mathrm{~Hz}\right), 25.0 .17 .2 .16 .5 ;{ }^{31} \mathrm{P}$ NMR $(121$ $\left.\mathrm{MHz} . \mathrm{CDCl}_{3} .25{ }^{\circ} \mathrm{C}\right): \delta=83.59$ : IR $(\mathrm{KBr}): v=3319.9$. 3240.3. 2961.2. 1458.8. 1420.8. 1135.9. 1021.5, $690.2 \mathrm{~cm}^{-1}$ : HR-MS (EI): $m z=412.2256$, exact mass calcd. for $\left[\mathrm{C}_{18} \mathrm{H}_{4} \mathrm{~N}_{2} \mathrm{P}_{2} \mathrm{~S}_{3}\right]^{+}: 412.2264$

Synthesis of $N, N^{\prime}$-bis ( $P, P$-diisopropylthiophosphinyl)2,2-dimethyl-1,3-propanediamine (11). To a solution of 2,2-dimethylpropane-1.3-dianine (255.0 $\mathrm{mg}, 2.5 \mathrm{mmol}$ ) and $N, N$-diisopropyl-ethylamine $(1.96 \mathrm{~mL} .11 .3 \mathrm{mmol})$ in dichloromethane $(5 \mathrm{~mL})$ was added dropwise chlorodiisopropylphosphine $(0.8 \mathrm{~mL} .5 .0 \mathrm{munol})$ dissolved in dichloromethane $(3 \mathrm{~mL})$ with stirring at $0{ }^{\circ} \mathrm{C}$. The reaction mixture was allowed to warm to $25^{\circ} \mathrm{C}$ and it was stirred overnight. Sulfur ( $170.0 \mathrm{mg}, 5.3 \mathrm{mmol}$ ) was added in small portions to the resulting mixture. The reaction mixture was stirred for 2 $\mathrm{h}$ at room temperature and then. it was concentrated in vato. The residue was purified by colunun cluromatography on silica gel to give 11 (710.0 mg. $72 \%)$, using $20 \%$ ethyl acetate in $n$-hexane for elution. Recrystallization from methylcyclohexane gave $11(670.0 \mathrm{mg} .68 \%)$ as a white solid (m.p. $\left.143-1+4{ }^{\circ} \mathrm{C}\right) .{ }^{1} \mathrm{H}$ NMR $\left(500 \mathrm{MHz} . \mathrm{C}_{6} \mathrm{D}_{6} .25^{\circ} \mathrm{C}\right.$ ): $\delta=2.95$ (t. $J=8.0 \mathrm{~Hz}, 4 \mathrm{H} . \mathrm{CH}$ ), 2.67 (q. $J=8.0 \mathrm{~Hz}, 2 \mathrm{H}$. NH). 2.10 (septet, $J=7.0 \mathrm{~Hz} .4 \mathrm{H}, \mathrm{CH}) .1 .11(\mathrm{~d}, J=7.0 \mathrm{~Hz}$. $\left.6 \mathrm{H} . \mathrm{CHCH})_{3}\right) .1 .07\left(\mathrm{t}, J=5.75 \mathrm{~Hz} .12 \mathrm{H} . \mathrm{CHCH}_{3}\right) .1 .03(\mathrm{~d} . J$ $\left.=7.0 \mathrm{~Hz}, 6 \mathrm{H}, \mathrm{CHCH}_{3}\right), 0.82\left(\mathrm{~s}, 6 \mathrm{H}, \mathrm{C}\left(\mathrm{CH}_{3}\right)_{2}\right) ;{ }^{13} \mathrm{C}$ NMR $\left(125 \mathrm{MHz} . \mathrm{C}_{6} \mathrm{D}_{6}, 25^{\circ} \mathrm{C}\right): \delta=47.4,31.1,30.6 .24 .1 .17 .0$. 17.0: ${ }^{31} \mathrm{P}$ NMR (121 MHz. $\mathrm{C}_{6} \mathrm{D}_{6} .25^{\circ} \mathrm{C}$ ): $\delta=89.54$ : IR (KBr) $v=3324.3,3207.0 .2974 .0 .1446 .5 .1073 .8 .829 .8,708.4$ $\mathrm{cm}^{-1}$; HR-MS (EI): $m z=398.2097$. exact mass calcd. for $\left[\mathrm{C}_{17} \mathrm{H}_{+(1} \mathrm{N}_{2} \mathrm{P}_{2} \mathrm{~S}_{3}\right]^{+} 398.2108$.

Typical procedure for intramolecular hydroaminations of aminoalkynes using yttrium complexes 13. In an argonfilled glove box. Y[N(TMS) $]_{3}$ ( $11.4 \mathrm{mg}, 0.02 \mathrm{mmol}$ ) and $N . N^{\prime}$-bis(2-isopropy lphenyl)ethane-1,2-diamine (t) $(5.93$ mg. $0.02 \mathrm{mmol})$ in $\mathrm{C}_{6} \mathrm{D}_{6}(0.4 \mathrm{~mL})$ were introduced sequentially into a J. Young NMR tube with Teflon screw cap purchased from Aldrich or $\mathrm{J}$. Young Ltd. The reaction mixture was stirred at $120^{\circ} \mathrm{C}$ for 5 days until ligand attachment was judged completely by the disappearance of the $\mathrm{Y}\left[\mathrm{N}(\mathrm{TMS})_{2}\right]_{3}$ with conconitant generation of the free (TMS) $)_{2} \mathrm{NH}$. The appropriate aminoalkynes $(0.4 \mathrm{nmol})$ and and $p$-xylene $(4.9 \mathrm{~mL} .0 .04 \mathrm{mmol})$ were added to the resulting complex via microsyringe and the reaction mixture was subsequently heated at corresponding temperature in an oil bath untill hydroamination was judged complete by disappearance of the starting metarial in the ${ }^{3} \mathrm{H}-\mathrm{NMR}$ relative to the aromatic resonance of the internal standard $p$ sylene.

Typical procedure for intramolecular hydroaminations of aminoalkynes using yttrium complexes 15 . In an argonfilled glove box. Y[N(TMS) $]_{3}$ ( $11.4 \mathrm{mg} .0 .02 \mathrm{mmol}$ ) and $N, N^{\prime}$-bis( $P . P$-diisopropylthiophosphinyl)-2,3-dimethyl-2,3butanediamine (9) $(8.25 \mathrm{mg}, 0.02 \mathrm{mmol})$ in $\mathrm{C}_{i} \mathrm{D}_{6}(0.4 \mathrm{~mL})$ were introduced sequentially into a I. Young NMR tube with Teflon screw cap. The reaction mixture was stirred at $120^{\circ} \mathrm{C}$ for 10 days until ligand attaclunent was judged completely by the disappearance of the $\mathrm{Y}\left[\mathrm{N}(\mathrm{TMS})_{2}\right]$; with concomitant generation of the free (TMS) $2 \mathrm{NH}$. The appropriate aminoalkynes $(0.4 \mathrm{mmol})$ and and $p$-xylene $(4.9 \mathrm{~mL}, 0.04 \mathrm{mmol})$ were added to the resulting complex via micro syringe and the reaction mixture was subsequently heated at corresponding temperature in an oil bath untill hydroamination was judged complete by disappearance of the starting metarial in the ${ }^{1} \mathrm{H}-\mathrm{NMR}$ relative to the aromatic resonance of the internal standard $p$-sylene.

Zr(IV) bis(thiophosphinic amidate) complex (16). In an argon-filled glove box. $\mathrm{Zr}\left(\mathrm{NMe}_{2}\right)+(20 \mu \mathrm{L}, 0.02 \mathrm{mmol} .1 .0$ $\mathrm{M}$ solution in benzene-d or toluene-ds) and $N, N^{\prime}$-bis $(P . P$ disopropylthiophosphinyl)-2,2-dimethyl-1,3-propanediamine (7.97 mg. $0.02 \mathrm{mmol})$ in $\mathrm{C}_{6} \mathrm{D}_{6}(0.4 \mathrm{~mL})$ or toluene- $\mathrm{d}_{8}(0.4$ $\mathrm{mL}$ ) were introduced sequentially into a J. Young NMR tube. The reaction mixture was stirred at $25^{\circ} \mathrm{C}$ for $10 \mathrm{~min}$ until ligand attachment was judged completed by the disappearance of the $\mathrm{Zr}\left(\mathrm{NMe}_{2}\right)_{4}$ resonance in the ${ }^{{ }^{1} \mathrm{H}} \mathrm{NMR}$ spectrum with concomitant production of $\mathrm{Me}_{2} \mathrm{NH}$. ${ }^{1} \mathrm{H}$ NMR $\left(500 \mathrm{MHz} . \mathrm{C}_{6} \mathrm{D}_{\text {i. }} .25^{\circ} \mathrm{C}\right.$ ): $\delta=3.11$ (s. $12 \mathrm{H}, \mathrm{Zr}\left[\mathrm{N}\left(\mathrm{CH}_{3}\right)_{2}\right]_{2}$ ), 2.69 (d. $J=10.0$ Hz. 4 H. CH. $) .1 .99$ (septet. $J=7.25$ Hz. 4H. CH). $\left.1.16(\mathrm{~d}, J=7.0 \mathrm{~Hz}, 6 \mathrm{H}, \mathrm{CHCH})_{3}\right), 1.13(\mathrm{dd} . J=7.0 \mathrm{~Hz}$, $\left.J=1.5 \mathrm{~Hz} .12 \mathrm{H} . \mathrm{CHCH}_{3}\right), 1.09\left(\mathrm{~d}, J=7.0 \mathrm{~Hz} .6 \mathrm{H}, \mathrm{CHCH}_{3}\right)$, 0.89 (s. $\left.\left.6 \mathrm{H} . \mathrm{C}\left(\mathrm{CH}_{3}\right)\right)_{2}\right){ }^{13} \mathrm{C}$ NMR $\left(125 \mathrm{MHz} . \mathrm{C}_{6} \mathrm{D}_{6} .25^{\circ} \mathrm{C}\right): \delta$ $=57.9,44.1 .29 .1 .28 .7,26.4,17.7,16.7 ;{ }^{31} \mathrm{P}$ NMR (121 $\mathrm{MHz}, \mathrm{C}_{6} \mathrm{D}_{6} .25^{\circ} \mathrm{C}$ ): $\delta=75.10$; Elemental analysis calcd. (\%) for $\mathrm{C}_{21} \mathrm{H}_{50} \mathrm{~N}_{4} \mathrm{P}_{2} \mathrm{~S}_{2} \mathrm{Zr}$ : C 43.79, H 8.75. N 9.73: found: $\mathrm{C}$ 43.74. H 8.73. N 9.69.

Typical procedure for intramolecular hydroaminations of aminoallenes using NPS $\mathrm{Zr}\left(\mathrm{NMe}_{2}\right)_{2}$ complexes (16). In an argon-filled glove box. $\mathrm{Zr}\left(\mathrm{NMe}_{2}\right)_{+}(20 \mu \mathrm{L}$. $0.02 \mathrm{mmol}$, $1.0 \mathrm{M}$ solution in benzene-d $\mathrm{s}$ ) and $N^{\prime} N^{\prime}$-bis $(P, P$-diisopropylthiophosphinyl)-2,2-dimethyl-1.3-propanediamine (7.97 $\mathrm{mg}$. $0.02 \mathrm{mmol})$ in benzene- $\mathrm{d}_{\delta}(0.4 \mathrm{~mL})$ or toluene- $\mathrm{d}_{\delta}(0.4 \mathrm{~mL})$ were introduced sequentially into a J. Young NMR tube. The reaction mixture was stirred at $25^{\circ} \mathrm{C}$ for $10 \mathrm{~min}$ until ligand attachment was judged completed by the disappearance of the $\mathrm{Zr}\left(\mathrm{NMe}_{4}\right)_{4}$ resonance in the ${ }^{1} \mathrm{H}$ NMR spectrum with concomitant production of $\mathrm{Me}_{2} \mathrm{NH}$. The appropriate aminoallene $(0.40 \mathrm{mmol})$ and $p$-xylene $(10.0 \mu \mathrm{L} .0 .08 \mathrm{mmol})$ were added to the resulting solution and then. the reaction mixture was subsequently heated at $75^{\circ} \mathrm{C}$ in an oil bath to achieve hydroamination.

Acknowledgments. This work was supported by Korea Research Foundation Grant (KRF-2003-005-C00021). Hỵunseok Kim has been granted the Seoul Science Fellow- 
ship. NMR and mass data were obtained from the central instrumental facility in Kangwon National University.

\section{References and Notes}

1. (a) Müller. T. E.: Beller. M. Chem. Rev. 1998. 98.675 . (b) Burling. S.: Field. L. D.: Messerle. B. A. Organontetallics 2000. 19. 87. (c) Müller. T. E.: Grosche. M.: Herdtweck. E.: Pleier. A.-K.: Walter. E.: Yan, Y.-K. Organometallics 2000. 19. 170. (d) Vasen. D.: Salzer A.: Gerhards. F: Gais. H.-J: Stlirmer. R.: Bieler, N. H.: Togni. A. Organometalics 2000, 19, 539. (e) Kawatsura. M: Hartwig. J. F. J. Am. Chent Soc. 2000. 122. 9546. (f) Haak. E.: Siebeneicher. H.: Dove. S. Org. Lett. 2000. 2. 1935. (g) Johnson. J. S.: Bergman. R. G. J. Am. Chem. Soc. 2001. 123. 2923. (h) Pohlki, F.: Dove. S. Chem. Soc. Rev 2003. 32, 104. (i) Bytschkov, I.: Dove S. Eur. J. Org. (Them. 2003 935. (j) Alonso, F: Beletskaya. I. P.: Yus. M. Chem. Rev. 2004. 104. 3079.

2. 2. (a) Gagne. M. R.: Marks. T. J. J. Am. Chent. Soc. 1989. HI, 4108. (b) Gagné. M. R.: Nolan. S. P.: Marks. T. J. Orgonometallics 1990. 9. 1716. (c) Gagne. M. R.: Brard. L.: Conticello. V. P.: Giardello. M. A.: Stem, C. L.: Marks, T. J. Orgamometalics 1992, 11, 2003. (d) Li. Y: Fu, P.-F.: Marks, T. J. Organometallics 1994, 13. 439. (e) Giardello, M. A.: Conticello, V. P: Brard. L.: Gagné. M. R.: Marks. T. J. J. Am. Chem. Soc. 1994. 116. 10241. (t) Li. Y.: Marks. T. J. J. Am. Chem. Soc. 1996. 118.707. (g) Li. Y: Marks. T. J. Organontetallics 1996. 15. 3770. (h) Li. Y: Marks, T. I. J. Am. Chem. Soc. 1996, 118, 9295. (i) Hong. S.: Marks, T. I. J. Am. Chem. Soc. 2002. 124. 7886. (j) Gribkot, D. V.: Hulzsch, K. C.: Hampel. F. Chem. Eur. J. 2003. 9, 4796. (k) Ryu. J.-S.: Li. G. Y.: Marks. T. J. J. Am. Chen. Soc. 2003.125. 12584. (1) Hong. S.: Tian. S.: Metz. M. V.: Marks. T. J. J. Am. Chem. Soc. 2003. 125. 14768. (m) Hong. S.: Kawaoka. A. M.: Marks. T. I. J. Am. Ghem. Soc. 2003. 125. 15878 . (n) Gribkov, D. V. Hultzsch. K. C. Angew (Chem. hit. Ed. 2004, 43. 5542. (o) Hultzsch. D. K. C.: Hampel F.: Wagner. T. Organometallics 2004. 23.2601

3. (a) Gagne. M. R.: Stern. C. L.: Marks. T. J. J. Am. Chem Soc. 1992. 114.275 . (b) Molander. G. A.: Dowdy. E. D. J. Org Chent. 1998, 63, 8983. (c) Tian. S: Arredondo, V. M.: Stern. C. L:
Marks. T. J. Organonetallics 1999. 18. 2568. (d) Ruy. T.-S. Marks. T. J.: McDonald. F. E. Ong. Lett. 2001. 3. 3091.

4. (a) Bürgstein. M. R.: Berberich. H.: Roesky. P. W. Organometallics 1998. 17, 1452. (b) Arredondo, V. M.: Tian. S.: McDonald, F. E.; Marks, T. J. J. Am. Chem. Soc. 1999. 121, 3633. (c) Duncan. D.; Livinghouse. T. Organometallics 1999. 18, 4121 . (d) Hong. S.: Marks. T. J. Acc. Chent. Res. 2004. 39. 673. (e) Ryu. J.-S.: Marks. T. J.: McDonald. F. E. J. Ong. Chem. 2004. 69. 1038.

5. (a) Kiml. Y. K.: Livinghouse. T.: Bercaw. J. E. Tetrahedron Lett. 2001. +2, 2933. (b) Kim. Y. K.: Livinghouse. T. Angew. Chem. In. Ed. 2002. 41.3645. (c) Kim, Y. K.: Livinghouse. T.: Horino, Y. J Am. Chem. Soc, 2003. 125, 9560. (d) Kim, H: Lee, P. H: Livinghouse. T. Chent Conmmm. 2005. 5205. (e) Kim. J. Y: Livinghouse. T. Org. Lett. 2005. 7. 4391. (f) Kim. J. Y.: Livinghouse. T. Org. Lett. 2005. 7. 1737. (g) Kim. H.: Livinghouse. T.: Shim. J. H.: Lee. S. G; Lee, P. H. Adv. Synth. Catal. $2006,348$. 701

6. (a) Shi. Y.: Ciszewski, J. T: Odom, A. L. Organometallics 2001. 20. 3967. (b) Ackermann. L.: Bergman. R. G. Org. Lett. 2002. t. 1475. (c) Ackermann. L.: Bergmant. R. G.: Loy. R. N. J. Ain. Chent Soc. 2003. 125. 11956. (d) Hoover. I. M.: Peterset1. J. R.: Pikul, J.: Johnson. A. R. Organometallics 2004, 23, 4614.

7. Lappert, M. F; Power. P. P.: Sanger. A. R; Srivastava. R. C. Metal and Retalloid Amides: Wiley: New York 1980.

8. ${ }^{1} \mathrm{H}$ NMR $\left(\mathrm{C}_{\mathrm{s}} \mathrm{D}_{\text {s. }} 500 \mathrm{MHz}\right) \delta 3.11$ (s. $\left.12 \mathrm{H} . \mathrm{Zr}\left[\mathrm{N}(\mathrm{CH})_{2}\right)_{2}\right) .2 .69$ (d. $\left.J=10.0 \mathrm{~Hz} .4 \mathrm{H} . \mathrm{CH}_{2}\right) .1 .99$ (septet. $J=7.25 \mathrm{~Hz} .4 \mathrm{H} . \mathrm{CH}$ ). 1.16 (d. $J=7.0 \mathrm{~Hz} .6 \mathrm{H}$. $\mathrm{CHCH}_{3}$ ). 1.13 (dd. $J=7.0 .1 .5 \mathrm{~Hz} .12 \mathrm{H}$. $\left.\mathrm{CHCH} H_{3}\right) .09(\mathrm{~d} . J=7.0 \mathrm{~Hz} .6 \mathrm{H}, \mathrm{CHCH})_{3} 0.89\left(\mathrm{~s}, 6 \mathrm{H} . \mathrm{C}\left(\mathrm{CH}_{3}\right)_{2}\right)$. ${ }^{13} \mathrm{C}$ NMR $\left(\mathrm{C}_{6} \mathrm{D}_{6 .} 125 \mathrm{MHz}\right)$ o 57.87. $41.10,29.08 .28 .67,26.43$. $17.68,16.69 .{ }^{3} \mathrm{P} N M R\left(\mathrm{C}_{6} \mathrm{D}_{\text {i. }} 121 \mathrm{MHz}\right) \delta 75.10$. Anal. Calcd for $\mathrm{C}_{21} \mathrm{H}_{31} \mathrm{~N}_{4} \mathrm{P}_{2} \mathrm{~S}_{2} \mathrm{Zr}:$ C. 43.79: H. 8.75: N. 9.73. Found: C. 43.74: H. 8.73: N. 9.69 .

9. Burgstein. M. R.: Berberich. H.: Roesky. P. W. Chent. Ent J. 2001. 7, 3078

10. J. Young NMR tubes. purchased from Aldrich or J. Young Ltd, were used under refluxing conditions (bath temperature. $120^{\circ} \mathrm{C}$ or $150^{\circ} \mathrm{C}$ ) without any special precautions.

11. (a) Ward. B. D.: Maisse-Francois. A.: Mountford. P.: Gade. L. H. Chent Commm 2004. 704. (b) Li. Y.: Shi. Y.: Odom. A. L. J. Ant. Chem. Soc. 2004, 126. 1794 